\title{
OBITUARY
}

\section{GEORGE STRONG DERBY, of Boston, Mass.}

THE death of Dr. George S. Derby was noted in our last number. He quickly succumbed to an attack of pneumonia at the end of last, year. He was born in May, 1875, the son of Dr. Hasket Derby, who was a pioneer of ophthalmology in the United States.

A memoir by Dr. Harvey Cushing contributed to the New England Journal of Medicine (Vol. CCV., pp. 1262-1264), 1931, gives interesting details of G. S. Derby's ancestry. It appears that Roger Derby emigrated from Devonshire in 1671 to America, and settled at Ipswich. After the death of his first wife he moved to Salem and married Elizabeth Hasket. Their male descendants became famous shipowners, merchants and mariners and were largely instrumental in making Salem the leading American port.

After receiving his preliminary. education, the younger Derby entered Harvard and took his B.A. in 1896. At this time he was prominent as an oarsman. He then entered the Harvard Medical School and was resident interne in the Massachusetts General Hospital. This was followed by a foreign tour, during which he worked in Vienna and at Moorfields, visiting also Berlin, France and Holland.

On his return to Boston in 1901 he set up in practice in his native city, where he held many appointments. He was much respected both in the United States and in this country, where he had many friends. Dr. Derby held the Williams Chair of Ophthalmology at Harvard and had been president of the Suffolk District Medical Society, and chairman of the ophthalmological section of the American Medical Association. He also served on the staff of the Massachusetts Eye and Ear Infirmary and Commission for the Blind.

He saw active service in 1917-1918, when he was attached to Base Hospital No. 5, with which he sailed for France. Shortly after arrival he worked in various casualty clearing stations and was promoted Major in 1918. He was later transferred to the Headquarters Staff of Consultants to the American Expeditionary Force as an ophthalmic surgeon, and became Lieut.-Colonel in October, 1918. He returned home in January, 1919. He was specially cited in despatches by General Pershing. Dr. Derby married in 1901 and leaves a widow and two children to mourn his loss. His mother also is still alive. The heartfelt sympathy of British ophthalmology will go out to them in their bereavement.

Sir William Lister writes:

George Derby became known to English ophthalmic surgeons in the early years of 1900 , when he worked at Moorfields, but it 
was during the War-when he came to France in the Harvard Unit-that by his strong personality, his power as a worker, his selflessness, and his charm as a companion, he became widely known and loved.

When the American Army came to France he was appointed Consulting Ophthalmic Surgeon to the Army in conjunction with Dr. Greenwood, and did brilliant work both as an organiser and as a clinician. Before this he worked as Ophthalmic Specialist for the British Army, both in the Harvard Unit and also at the English Ophthalmic Centre at Boulogne, rendering very valuable service. There was never a task so trivial but he did it with alacrity, nor was there a problem so difficult but he would whole heartedly discuss it and throw new light on it. All who worked with him were aware of his high ideal of service, and though he was extremely reticent, those who knew him well appreciated that this was based on deep religious conviction.

In later years at the English Speaking Ophthalmic Convention in London, and at the International Ophthalmological Congress in Holland, he, with his genial cheery face and great broad shoulders, was constantly a centre to which many were drawn by his personal magnetism.

He was a man of sterling uprightness and of great sympathy. His judgments both of people and in his professional work were wise and kindly, enlivened by a happy sense of humour, and it was almost unknown for him to make a disparaging criticism of anyone.

The loss of George Derby will be deeply felt, both in his own country and in England, by a large circle of acquaintances, while to his many friends his death leaves a blank which it is impossible to fill.

\section{NOTES}

Death

WE announce with regret the sudden death on November 29, 1931, of Professor Roselli, of Rome, who was the Italian representative on the International Council of Ophthalmology.

We are indebted to Professor Ovio, through the courtesy of Dr. Marx, for giving us this information and for the facts which follow :-

Romeo Roselli was a scion of a well-known Roman family and was born in 1866. His interests were mainly centred in the scientific side of ophthalmology, and he was the author of many 